\title{
施設入居高齢者の身体機能の特性 一転倒予防の観点から一
}

\author{
小松 泰喜1) 田中 尚喜 ${ }^{12}$ 武藤 芳照 ${ }^{2}$ 太田 美穗 ${ }^{21}$
}

\begin{abstract}
〈要 約〉長寿社会を迎え, 高齢者が健やかな社会生活を過ごすために, 個人の身体機能に合った住環境 の整備が重要である.そこで高齢者の適切な運動・生活指導のための基礎資料を得ることを目的としてバリ アフリー型施設に入居する高齢者の身体機能について検討を行った. 施設入居高齢女性 18 名（平均 80.7 歳： 72 87以下，施設群）と東京厚生年金病院「転倒予防教室」に自発的に参加した高齢女性20名（平均年齢78.3 歳：75 86以下, 教室群) の計38名を対象とした. 測定項目は(1)体型および体格評価として, 身長, 体重か ら体格指数 BMI をウエスト, ヒップ值からウエスト・ヒップ比を算出した. (2)健脚度 (10m 全力歩行, 最 大 1 歩幅, 40cm 踏台昇降の可否), (3)重心動摇計（アニマ社製 GravicorderG5500）等であった．統計処理 は, 対応のある場合の T-テストを用い両群間の各々のデータより比較検討した．健脚度では, 教室群に比 べ, 施設群の方が歩行速度, 歩数, 最大一歩幅, 最大一歩幅/下肢長で有意に劣っていた $(\mathrm{p}<0.01)$. 特に, $40 \mathrm{~cm}$ 踏台昇降では, 自力で昇降不能な者が多く $\chi^{2}$ 検定の結果，両群間に有意な分布の隔たりを認めた $(\mathrm{p}$ <0.01). また. さらに重心動摇についても開閉眼時ともに施設群において総軌跡長, ロンベルグ率などで 有意に劣っていた $(\mathrm{p}<0.01)$.

近年，バリアフリーの概念の普及から病院，公共施設から一般住宅まで住環境が変化してきている．しか し，住環境だけを改善することは，高齢者の身体機能の低下に拍車を掛ける可能性がある．そのため施設内 に訓練用の段差や悪路なども設置して使用を促すことだけでなく, 高齢者自身が活発な日常生活を送ること を励まし, 歩行訓練や楽しく無理のない多様な運動指導を実践する総合的な対応が必要と考えられた.
\end{abstract}

Key words : バリアフリー, 転倒子防, 健脚度, 高齢者, 重心動摇

（日老医誌 $2000 ； 37 ： 908-911 ）$

\section{緒言}

長寿社会を迎え，高齢者や障害者の社会環境をより安 全に，より快適にするため，個人の身体機能に合った住 環境の整備が重要である.

近年，ハンディキャップを負っている人々の行動を阻 む物的・制度的・心理的障壁がないという意味”のバリ アフリーデザインは物的障壁除去設計であり，その設計 対象の範囲と内容は極めて広範囲であるため, このよう な「バリアフリー」の概念の普及から, 高齢者の転倒 · 転落事故の予防のため, 段差の解消や手すりの設置など 構造上の工夫を取り入れた各種公共施設や一般家屋が増 加してきている.

高齢者の体力 ·運動能力, 運動機能については, 加齢 に伴って低下すること, その内容は, 加齢変化と身体活 動の不足の総和であること, 運動習慣が年齢により低下

1）T. Komatsu, N. Tanaka：東京厚生年金病院リハビリ

テーション室

2) Y. Mutou, M. Ohta：東京大学大学院身体教育学講座 受付日：1999. 8.16, 採用日：2000.8.9
しその度合が変化することなどが知られている かし, 生活環境や住環境と高齢者の運動機能との関係に ついての報告はきわめて少ない.

そこで, 今後の高齢者の転倒予防の観点から, 適切な 運動・生活指導および建物構造における工夫のための基 礎資料を得ることを目的として, 著者らは,バリアフリー 型施設に入居する高齢者の身体特性を，転倒回避能力を 中心に検討したところ, 若干の知見を得たので報告する.

\section{方法}

対象は, 茨城県下にある自立生活者のための某バリア フリー型ケアーホームに入居している高齢女性18名（平 均年齢 $80.7 \pm 4.4$ 歳, (75歳 86 歳), 平均入居期間 11.9 力 月（1２5力月)) と東京厚生年金病院健康管理センター 『転倒予防教室』910) (健康診断の後, 運動・生活指導を 8 週間, 計 6 回の直接指導) に自発的に参加した高齢女性 20 名（平均年齢78.3 \pm 3.0 歳（72歳～87歳)）である. 前者 を「施設群」, 後者を「教室群」とした。

なお，年齢で両群間に有意差はなかった。

測定項目は, (1)体型および体格評価として, 身長, 体 
Table 1 Comparison with Physical Characteristics

\begin{tabular}{c|r|r|c}
\hline & Home & School & \\
\hline Height $(\mathrm{cm})$ & $149.79 \pm 5.52$ & $147.12 \pm 5.84$ & N.S. \\
Weight $(\mathrm{kg})$ & $52.65 \pm 8.62$ & $50.96 \pm 8.71$ & N.S. \\
BMI & $23.44 \pm 3.57$ & $23.51 \pm 3.43$ & N.S. \\
Waites/Hip Ratio & $0.93 \pm 0.07$ & $0.88 \pm 0.07$ & N.S. \\
\hline \multicolumn{3}{|c}{ N.S. : Not Significantly }
\end{tabular}

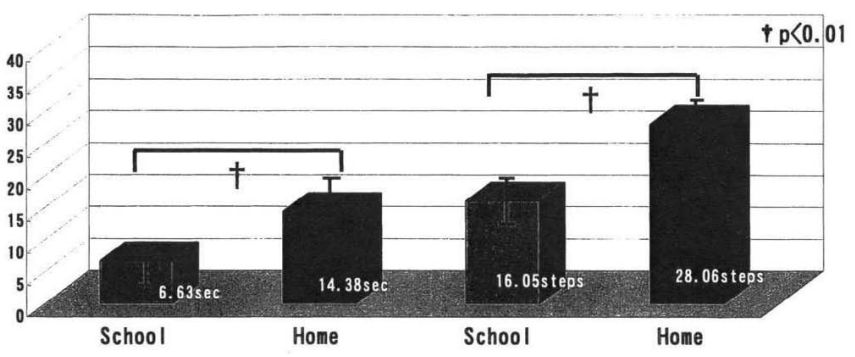

Fig. $110 \mathrm{~m}$ Walking Time (sec) and $10 \mathrm{~m}$ Walking Number of Steps

In measuring, extra 2 meters provied, respectively in front of the start line and behind the goal line, for the elderly to accelerate, Therefore, the tested elderly walked 14 meters in all at full speed and the time used for walking 10 meters was measured with a stop watch. After a practice walk, the test was done.

重から体格指数 Body Mass Index（以下，BMI）を，ウ エスト，ヒップ值からウエスト・ヒップ比をそれぞれ算 出した.

また(2)運動機能，特に転倒回避能力の測定・評価項日 として, 健脚度"1を用いた. 3 つの測定・評価項目から 10 $\mathrm{m}$ 全力歩行では, 歩行速度と平均歩幅を算出した. 最 大一歩幅では，両脚を揃えた状態から最も大きくあるい はできるだけ広く片方の脚を踏み出し, 反対側の脚をそ の横にそろえ，その爪先までの距離を測り，さらにト肢 長比から補正值も求めた. $40 \mathrm{~cm}$ 踏台昇降は, 高さ $40 \mathrm{~cm}$ の台を手すりなしで確実に昇り，いったん台上で両脚を そろえて直立した後, 向こう側へ着実に降りることがで きるかどうかを判定した，判定方法としては，「楽に昇降 できる：可」,「着地でふらつくあるいは手を膝に当てれ ば昇降できるあるいは横向きならば降りられる：困難」, 「全く昇降できない：否」の三段階に分けた.

(3)平衡機能評価として, 開眼時, 閉眼時の重心動摇計 （アニマ社製 GravicorderG5500）における総軌跡長，総 軌跡長におけるロンベルグ率, 単位軌跡長, 単位面積軌 跡長, $\mathrm{X}$ 方向最大振幅, $\mathrm{Y}$ 方向最大振幅, 最大振幅の各 種パラメーターを測定した。

統計処理は，対応のない場合の T-テストを用い，両

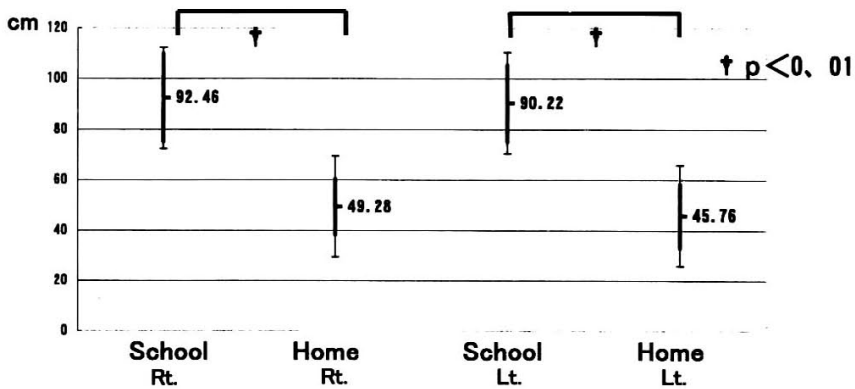

Fig. 2 Maximum Width of a Step The maximum width of a step, which is the measurement with the maximum degree of endeavor from standing-straight position and both legs together, was measured with a measuring tape. After a practtice step, a test was done with each left and ringth foot. The adjustment was made by dividing the average of each foot by the length of lower limbs (spina malleollar distance).

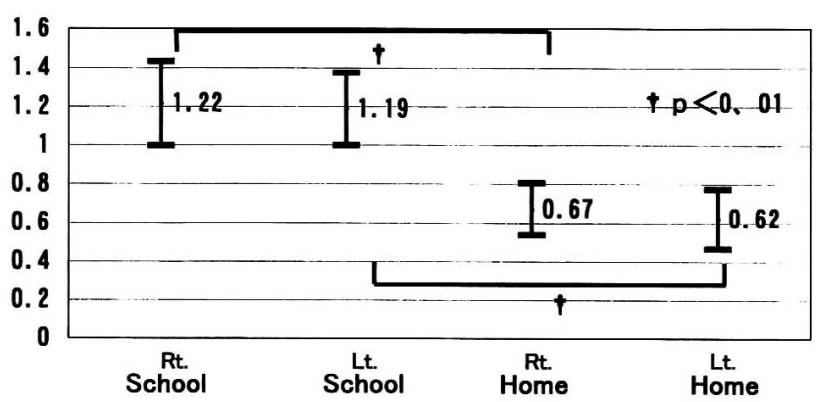

Fig. 3 Maximum Length of a Step by the Length of Lower Limbs

Table $240 \mathrm{~cm}$-staircase stepping

\begin{tabular}{c|c|c|c|c}
\hline & Easy & Barely & Impossible & Total \\
\hline Home & 0 \\
School & 7 & 4 & 14 & 18 \\
\hline & 11 & 2 & 20 \\
\hline
\end{tabular}

The examinar's observed whether or not the elderly can step completely on a $40 \mathrm{~cm}$-staircase without a handrail, stand straight on the staircase with both legs together, and steadily come down from the staircase. Evaluation was done in 3 level ; 'easy' if the elderly can step up and down with ease, 'barely' if the elderly is frail when putting foot down or he/she can step up and down with his/her hands supporting the knees, 'impossible' if the elderly cannot step up and down at all.

群間の各々のデータより比較検討した。 
Table 3 Gravity Deviation to Gravinography Parameters

\begin{tabular}{|c|c|c|c|c|c|c|c|c|}
\hline & & $\begin{array}{c}\text { Total } \\
\text { Length }(\mathrm{cm})\end{array}$ & $\begin{array}{c}\text { Romberg } \\
\text { Ratio }\end{array}$ & $\begin{array}{l}\text { Length/Time } \\
(\mathrm{cm} / \mathrm{sec})\end{array}$ & $\begin{array}{l}\text { Length/Area } \\
(1 / \mathrm{cm})\end{array}$ & $\begin{array}{c}\text { X-Axis } \\
\text { Maximum } \\
\text { Deviation }(\mathrm{cm})\end{array}$ & $\begin{array}{c}\text { Y-Axis } \\
\text { Maximum } \\
\text { Deviation }(\mathrm{cm})\end{array}$ & $\begin{array}{c}\mathrm{X} / \mathrm{Y} \\
\text { Muximum } \\
\text { Deviation } \\
\text { Ratio }\end{array}$ \\
\hline \multirow{2}{*}{$\begin{array}{l}\text { Open } \\
\text { Eyes }\end{array}$} & Home & $73.96 \pm 32.01$ & $1.18 \pm 0.57$ & $2.47 \pm 1.07$ & $14.56 \pm 4.67$ & $3.95 \pm 1.52$ & $4.09 \pm 1.62$ & $1.07 \pm 0.31$ \\
\hline & School & $37.24 \pm 8.23$ & $1.51 \pm 0.29$ & $1.24 \pm 0.27$ & $21.38 \pm 7.11$ & $2.29 \pm 0.60$ & $2.18 \pm 0.58$ & $0.99 \pm 0.29$ \\
\hline \multirow{2}{*}{$\begin{array}{l}\text { Closed } \\
\text { Eyes }\end{array}$} & Home & $83.29 \pm 37.27$ & & $2.78 \pm 1.24$ & $14.50 \pm 5.19$ & $3.94 \pm 1.38$ & $4.10 \pm 1.33$ & $1.13 \pm 0.40$ \\
\hline & School & $56.05 \pm 17.92$ & & $1.87 \pm 0.60$ & $21.74 \pm 7.39$ & $2.70 \pm 0.86$ & $2.85 \pm 1.04$ & $1.09 \pm 0.26$ \\
\hline
\end{tabular}

\section{結 果}

(1)体形・体格については，身長，体重，BMI，ウエス ト・ヒップ比ともに，両群間において有意差はみられな かった（Table 1$)$.

(2)健脚度については，10m 全力歩行において,「教室 群」に比べ,「施設群」の方が，時間，歩数ともに有意に 劣っていた $(\mathrm{p}<0.01)$ (Fig. 1)。また，最大一歩幅では， 実測值および補正值（最大歩幅/下肢長）共に「施設群」 が「教室群」に対して有意に劣っていた $(\mathrm{p}<0.01)$ (Fig. $2,3)$. 特に, $40 \mathrm{~cm}$ 踏台昇降では,「施設群」において自 力で昇降不能な者が多く, $\chi^{2}$ 検定の結果，両群間に有意 な分布の隔たりを認めた $(\mathrm{p}<0.01)$ (Table 2$).$

(3)さらに重心動摇についても, 開眼時・閉眼時ともに 「施設群」において, 総軌跡長, 総軌跡長におけるロン ベルグ率, 単位軌跡長, 単位面積軌跡長, $X$ 万向最大振 幅，Y 方向最大振幅で有意に劣っていた $(\mathrm{p}<0.01)$ ( Table 3$)$.

\section{考察}

一般住宅に居住し，転倒予防への自発的取り組みの意 志を持ち, 運動・生活指導を受けている高齢者と, バリ アフリー型施設に入居し，特にそのような自発取り組み の意思と働きかけのない高齢者とで, 転倒回避能力とし ての健脚度および平衡機能に明らかな差が認められた。

諸家らの報告によれば(2)13)，日本人は諸外国に比べ， 生活様式と下肢長が短いことにより，転倒事故が少ない とされている．特に立ち上がり動作は，日本特有の生活 様式を反映した動作であり，筋力だけでなく重心移動に 伴いバランス機能を養うことが身体機能にとって非常に 有益であるとされている.

また，重心動摇と骨密度の関係を経年的に追った研究 では, 在宅高齢者よりも長期の入院高齢者において, 活 動量の低下から骨密度の減少が著明に認められ，バラン
ス障害と機能低下から転倒事故による骨折の危険が増加 したと報告されている

近年,「バリアフリー」の概念の普及から，病院，公共 施設から一般住宅まで住環境が変化してきている。 しか し，住環境だけを改善することは，高齢者の身体機能の 低下に拍車を掛ける可能性がある。

Shumway-Cook らは，転倒経験者に対し個別に行っ た機能評価から，訓練プログラムを与え，8～12週の間 に週 1 度の理学療法に加え, 週に5 7 回の自宅でのホー ムエクササイズを行った群でのバランス機能㧍よび歩行 スピードなどの歩行能力が改善したことを示している. また, 転倒頻度も減少し, 転倒予防に対する認識も深まっ たと報告している ${ }^{15}$.

今回の結果により高齢者の身体機能は, 生活環境の違 いおよび皘極的働きかけの有無により，大きく変化する ことが示された。したがって高齢者の転倒子防の観点か ら，バリアフリー型施設に入居する高齢者は言うに及ば ず，各種施設入居者に対して，施設のみに依存した指導 ・管理ではなく, 日常的に，適切な方法・内容の運動・ 生活指導の必要性が示唆された。また，施設内に訓練用 の段差や悪路などを設置する工夫も有用と考えられる が，大切なことは，高齢者自身が活発な日常生活を送る ことの指導・教育かつ励まし，転倒子防につながる正し い姿勢の歩行習慣の獲得や楽しく無理のない多様な運動 指導を実践する総合的な対応の確立と考えられる.

\section{文献}

1）建築大辞典：彰国社 $1993: 1354$.

2) Heitmann DK, Gossman MR, Shaddeau SA, Jackson JR: Balance Performance and Step Width in Noninstitutionalized, Elderly, Female Fallers and Nonfallers. Physical Therapy $1989 ; 69$ (11) : 923-931.

3) Bogle Thorbaln, LD, Roberta A Newton: Use of the Berg Balance Test to Predict Falls in Elderly Persons. Physical Therapy $1996 ; 76(6): 576-585$. 
4）武藤芳照, 太田美穂, 高杉伸一郎 : 高齢者の転倒予防の ための運動・生活指導. 臨床看護 $1997 ; 23(1) ： 76$-81.

5) Sudarsky L: Geriatrics : gait disorders in the elderly. $N$ Engl J Med 1990; $322: 1441-1446$.

6) 橋詰 謙, 伊藤 元, 丸山仁司, 斎藤 宏, 石川 誠： 立位保持能力の加齢変化. 日老医誌 $1986 ; 23: 85-92$.

7) Roberts $B$ : Effects of walking on balance among elderly. Nurs Res $1989 ; 38: 180-183$.

8）宮下充正, 武藤芳照 : 高齢者とスポーツ(高齢者のトレー ニング）東京大学出版会, $1986 ; 35-59$.

9）太田美穂, 武藤芳照, 黒柳律雄, 上野勝則：【高齢者骨 折の原因, 転倒について】東京厚生年金病院における「転 倒予防教室」の概要 Osteoporosis Japan 6 1998;3: 598 - 600 .

10）黑柳律雄, 上野勝則, 武藤芳照, 太田美穂：水中運動 · 水泳を利用した病院内での「転倒予防教室」の試み 水 と健康医学研究会誌 $1 ; 1998$ : (1) 41-48.
11）上岡洋晴, 太田美穂: 健脚度の測定は変形性脊椎症の運 動・生活ガイド（菊地臣一, 武藤芳照, 伊藤晴夫編）日 本医事新報社, $1998 ; 65$-67.

12) Aoyagi K, Ross PD, Davis JW, Wasnich RD, Hayashi T, Takemoto T:Falls Among Community-Dwelling Elderly in Japan. J Bone Miner Res 1998; 13 : 1468 - 1474.

13) Ross PD, Huang C:Hip Fracture Incidence for Both Caucasians and Japanese in Hawaii is Lower than North America. J Bone Miner Res 1997 ; 12 (Suppl 1) : 173S.

14）泉キヨ子, 平松知子, 牧本清子, 影近謙治: 重心動摇求 よび骨密度の経年的変化に伴う高齢者の転倒予測に関す る研究一在宅および入院高齢者を通して一. Osteoporosis Japan $51997 ; 3: 99-107$.

15) Shumway-Cook A, Gruber W, Baldwin M, Liao S: The effects of multidimensional exercise on balance, mobility, and fall risk in community-dwelling older adults. Physical Therapy $1997 ; 77$ (1) : 46-57 Jan.

Abstract

\section{Ability to Avoid Falls among Aged Residents in a Barrier-free Welfare Institution.}

\section{Taiki Komatsu ${ }^{\text {a) }}$, Naoki Tanaka ${ }^{\text {a) }}$, Yoshiteru Mutoh ${ }^{\text {b) }}$ and Miho Ohta-Fukushima ${ }^{\text {b) }}$}

This study was carried out to investigate the physical functions of the elderly, living in a barrier-free home for the aged and to obtain basic data for giving appropriate guidance on exercise and daily life. A total of 38 women were tested. These included 18 persons (aged 72 87: mean : 80.7) who were living in the home for the aged, and 20 (aged 75 86: mean : 78.3) who voluntarily participated in the "fall prevention school", established in Tokyo Kosei-Nenkin Hospital.

The following examinations were done : 1) BMI, Waist/Hip ratio;2) good walker's index consisting of $10 \mathrm{~m}$ walking times, maximum length of steps, and $40 \mathrm{~cm}$-staircase climbing; and 3) equilibrium examination done by gravinography. Statistical analysis was carried out using a paired t-test $(\mathrm{p}<0.01)$. Values for the "good- walker's index" were significantly lower in, the "home" group than in the "school" group $(\mathrm{p}<0.01)$. This was especially obvious with $40 \mathrm{~cm}$-staircase climbing. Many of the subjects from the institution group required assistance and there was a significant difference in the chisquire square distribution between the two groups. Furthermore, on gravinography, the "home" group had significantly inferior values in total length $(\mathrm{cm})$ and Romberg's ratio $(\mathrm{p}<0.01)$. It was clear that residents in the barrier-free home had a significant reduction in good-walker's index, indicating an apparent weakening of physical function.

Key words : Barrier-free, Fall prevention school, Good-walker's index, Gravinography

(Jpn J Geriat $2000 ; 37: 908-911$ )

a) Department of Rehabilitation Tokyo Kosei-Nenkin Hospital, Japan

b) Department of Physical and Health Education, Graduate School of Education, The University of Tokyo, Japan 